\title{
Pengaruh Pemberian CSR Dana Pendidikan dari PT. Internusa Jaya Sejahtera Terhadap Peningkatan Kesejahteraan Masyarakat
}

\author{
Samrotu Sa'adah ${ }^{1}$, Elvira Azis ${ }^{2}$ \\ ${ }^{1}$ Program Studi Manajemen Bisnis Telekomunikasi dan Informatika, FEB, Universitas Telkom, Bandung, Indonesia. \\ ${ }^{2}$ Program Studi Manajemen Bisnis Telekomunikasi dan Informatika, FEB, Universitas Telkom, Bandung, Indonesia.
}

\begin{abstract}
This study aims to determine the effect of CSR education funding on the level of community welfare in the Ulilin District in Merauke provided by PT. Internusa Jaya Sejahtera. This study uses quantitative methods. This type of research is causal research. The measurement scale used is using Likert Scale with 5 scales. Sampling techniques used is non-probability using the saturated sampling method for 50 respondents who received CSR. The results showed that the provision of CSR education funds had a positive effect on the level of welfare of the people of Ulilin District in Merauke. The coefficient of determination was $50.7 \%$ indicating that Education CSR had a simultaneous influence of $50.7 \%$ on the welfare of the people of Ulilin District in Merauke. The results of this study can be suggestions for the company to continue or improve CSR activities, especially in the field of education after seeing a considerable influence on the welfare of the community around the company.
\end{abstract}

Keywords: Corporate Social Responsibility; Public Welfare

\begin{abstract}
Abstrak.Penelitian ini bertujuan untuk mengetahui pengaruh pemberian CSR dana pendidikan terhadap tingkat kesejahteraan masyarakat di Distrik Ulilin Kabupaten Merauke yang diberikan oleh PT. Internusa Jaya Sejahtera. Penelitian ini menggunakan metode kuantitatif. Jenis penelitian ini adalah penelitian kausal. Skala pengukuran yang digunakan adalah dengan menggunakan Skala Likert dengan 5 skala. Teknik sampling atau penarikan sampel yang digunakan adalah non probability dengan menggunakan metode sampling jenuh kepada 50 responden penerima CSR. Hasil penelitian menunjukan bahwa pemberian CSR dana pendidikan berpengaruh positif terhadap tingkat kesejahteraan masyarakat Distrik Ulilin Kabupaten Merauke, Nilai koefisien determinasi sebesar 50.7\% menunjukkan bahwa CSR Pendidikan memberikan pengaruh secara simultan sebesar $50.7 \%$ terhadap kesejahteraan masyarakat Distrik Ulilin Kabupaten Merauke. Hasil penelitian ini dapat menjadi saran ataupun masukan bagi perusahaan untuk dapat terus melanjutkan ataupun meningkatkan serta lebih memantau kegiatan CSR terutama dalam bidang pendidikan setelah melihat pengaruh yang cukup besar bagi kesejahteraan masyarakat sekitar perusahaan.
\end{abstract}

Kata Kunci: Corporate Social Responsibility; Kesejahteraan Masyarakat

Correspondence.samrotus@gmail.com

History of article. Received: Oktober 2018, Revision: Januari 2019, Published: Maret 2019

\section{PENDAHULUAN}

Pada era globalisasi saat ini memperhatikan lingkungan adalah salah satu hal yang sangat penting bagi pelaku bisnis. Hal ini disebabkan banyak dari pemangku kepentingan menilai suatu kesehatan bisnis tidak hanya dari pendapatan atau profit yang didapatkan, tetapi juga dinilai dari tanggung jawab yang diberikan pelaku bisnis kepada lingkungan sekitar. Tanggung jawab sosial yang diberikan oleh pelaku bisnis sering disebut dengan istilah CSR (Corporate Social Responsibility). CSR merupakan suatu komitmen pelaku bisnis untuk berkontribusi terhadap pembangunan ekonomi yang berkelanjutan, bekerja dengan karyawan, keluarga mereka, dan masyarakat lokal (Mardikanto, 2014:93).

Tanggung jawab sosial perusahaan secara yuridis telah dinyatakan sebagaimana dalam Undang-undang No. 40 Tahun 2007, tentang Perseroan Terbatas, Bab V, Pasal 74. Dalam pasal tersebut dijelaskan tanggung jawab sosial dan lingkungan dari perusahaan atas eksistensinya dalam kegiatan bisnis. Fitri (2015:50) mengemukakan bahwa sebuah perusahaan yang menunjukan tanggung jawab sosialnya akan memberikan perhatian kepada pengingkatan kualitas perusahaan (profit); masyarakat, khususnya komunitas sekitar (people); serta lingkungan hidup (planet bumi). 
Sadar akan tugas dan tanggung jawab sosial seperti yang telah diamanatkan dalam UndangUndang, PT. Internusa Jaya Sejahtera yang merupakan perusahaan dibidang industri kelapa sawit yang berlokasi di Kabupaten Merauke sejak tahun 2013 secara kontinyu dan terprogram telah menerapkan konsep CSR dalam implementasi manajemen usahanya. Secara garis besar, strategi pelaksanaan CSR PT. Internusa Jaya Sejahtera mencakup beberapa wilayah yang ada di sekitar perusahaan di Kabupaten Merauke. Strategi pengembangan berdasarkan wilayah ini juga ditunjang oleh berbagai jenis kegiatan yang sesuai dengan karakteristik kegiatan masingmasing daerah, seperti layanan publik di bidang kesehatan, keagamaan dan pendidikan.

Program CSR dari PT. Internusa Jaya Sejahtera terbanyak yang disalurkan untuk dana Pendidikan. Untuk bidang Pendidikan CSR yang diberikan oleh PT Internusa Jaya Sejahtera meliputi pemberian material untuk pembangunan sekolah dan dana beasiswa Pendidikan. PT Internusa Jaya Sejahtera sangat peduli terhadap dunia pendidikan karena mereka menyadari akan pentingnya kualitas sumber daya manusia (SDM) bagi perbaikan kualitas hidup keluarga, masyarakat dan bangsa kita secara luas. Selain itu salah satu indikator untuk melihat apakah suatu daerah telah meningkat kesejahteraannya adalah dengan melihat tingkat pendidikan dan sarana pendidikan yang dimiliki oleh daerah tersebut.

\section{KERANGKA PENELITIAN \& HIPOTESIS Corporate Social Responsibility (CSR)}

Corporate Social Responsibility (CSR) menurut Pradipta dan Supriyadi (2013) merupakan suatu kegiatan sosial yang dilakukan perusahaan sebagai bentuk tanggung jawab perusahaan terhadap masyarakat luas. Mulyadi (2007) mengatakan bahwa tanggung jawab sosial adalah tanggung jawab perusahaan terhadap semua kegiatan yang mempengaruhi manusia, komunitas mereka dan lingkungan. Hal tersebut akan berdampak kepada kesejahteraan masyarakat.

\section{Manfaat CSR}

Mardikanto (2014:130-141) menyebutkan bahwa manfaat CSR dapat dibagi dalam tiga manfaat utama, yang pertama manfaat CSR bagi masyarakat. Memperhatikan masyarakat membuat perusahaan dapat berkontribusi terhadap peningkatan kualitas hidup masyarakat. Perhatian tersebut dapat dilakukan dengan cara melakukan aktivitas-aktivitas serta kebijakan yang dapat meningkatkan kesejahteraan, kualitas hidup, dan kompetensi masyarakat di berbagai bidang.

Yang kedua manfaat CSR bagi pemerintah. Melalui CSR akan tercipta hubungan antara pemerintah dan perusahaan dalam mengatasi berbagai masalah sosial, seperti kemiskinan, rendahnya kualitas pendidikan, minimnya akses kesehatan dan lainnya. Tugas pemerintah untuk menciptakan kesejahteraan bagi rakyatnya menjadi lebih ringan dengan adanya partisipasi pihak swasta (perusahaan) melalui kegiatan CSR.

Ketiga manfaat CSR bagi korporasi yaitu, mempertahankan dan mendongkrak reputasi serta citra merek perusahaan, kedua memperkuat "brand" perusahaan, lalu membedakan perusahaan dengan pesaing, terakhir yaitu melebarkan akses sumber daya, membuka akses untuk investasi dan pembiayaan bagi perusahaan apabila masalah yang lebih besar muncul dalam perusahaan.

\section{Indikator CSR}

Dalam penelitian ini penulis menggunakan indikator untuk mengukur CSR berdasarkan pendapat dari Suharto (2009:115) yaitu: Engagement, pendekatan awal pada masyarakat agar terjalin komunikasi dan relasi yang baik. Tahap ini berupa sosialisasi mengenai rencana pengembangan program CSR. Lalu assesment, identifikasi masalah dan kebutuhan masyarakat yang akan dijadikan dasar dalam merumuskan program.

Ketiga adalah plan of action, merumuskan rencana aksi. Perusahaan memperhatikan aspirasi masyarakat atau stakeholders di satu pihak dan misi perusahaan termasuk shareholders di lain pihak. Keempat yaitu action and facilitation, menerapkan program yang telah disepakati bersama. Monitoring, supervisi dan 
pendampingan merupakan kunci keberhasilan implementasi program. Terakhir yaitu evaluation and termination of reformation, menilai sejauh mana keberhasilan pelaksanaan program CSR di lapangan.

\section{Kesejahteraan Masyarakat}

Kesejahteraan Masyarakat menurut UndangUndang Republik Indonesia Nomer 11 Tahun 2009 adalah suatu kondisi terpenuhinya kebutuhan material, spritual, dan sosial warga negara agar dapat hidup layak dan mampu mengembangkan diri, sehingga dapat melaksanakan fungsi sosialnya.

\section{Indikator Kesejahteraan Masyarakat}

Biro Pusat Statistik Indonesia (2015) menerangkan bahwa guna melihat tingkat kesejahteraan rumah tangga suatu wilayah ada beberapa indikator yang dapat dijadikan ukuruan, antara lain yang pertama adalah tingkat pendapatan keluarga. Kedua komposisi pengeluaran rumah tangga dengan membandingkan pengeluaran untuk pangan dengan non-pangan. Ketiga yaitu tingkat pendidikan keluarga. Keempat tingkat kesehatan keluarga. Kelima kondisi perumahan serta fasilitas yang dimiliki dalam rumah tangga.

\section{Kerangka Pemikiran}

CSR dijelaskan sebagai suatu tanggung jawab sebuah organisasi terhadap dampak keputusan dan kegiatannya kepada masyarakat dan lingkungan yang terwujud dalam perilaku transparan dan etis yang sejalan dengan pembangunan berkelanjutan dan kesejahteraan masyarakat, mempertimbangkan harapan para pemangku kepentingan, sejalan dengan hukum yang ditetapkan dan normal perilaku internasional. CSR yang dilakukan oleh PT Internusa Jaya Sejahtera dengan memberikan program bantuan untuk masyarakat sekitar diharapkan meningkatkan kualitas kehidupan dan lingkungan yang bermanfaat karena akan memberikan dampak baik dari perusahaan itu sendiri.

Kerangka pemikiran penelitian ini dapat digambarkan sebagai berikut:

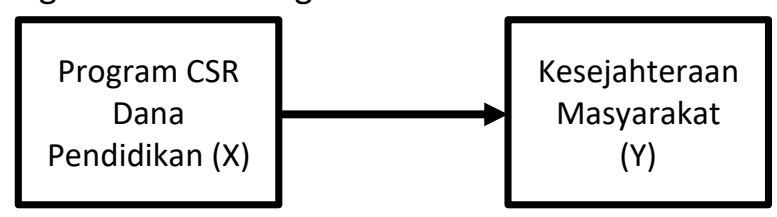

Gambar 1. Kerangka Pemikiran

Sumber: Hasil olahan penulis (2019)

Sumber indikator CSR: Suharto (2009:115)

Sumber indikator Kesejahteraan Masyarakat: BPS (2015)

\section{METODE PENELITIAN}

Dalam penelitian ini metode yang akan digunakan adalah metode kuantitatif. Metode kuantitatif merupakan metode yang menyaratkan variabel yang akan diteliti dapat diukur dan memungkinkan ketepatan dalam penelitian lebih baik karena penggunaan angka (Morissan, 2012:23). Jenis penelitian ini adalah penelitian kausal, menurut Sanusi (2013:14) penelitian kausal merupakan penelitian yang disusun guna meneliti hubungan sebab dan akibat yang terjadi pada variabel-variabel yang diteliti. Penelitian kausal ini akan digunakan untuk mengetahui dampak atau pengaruh pemberian CSR PT Internusa Jaya Sejahtera terhadap kesejahteraan masyarakat di Merauke.

Berikut variabel operasional penelitian ini yang digambarkan dalam tabel 1 berikut:

Tabel 1. Variabel Operasional

\begin{tabular}{|c|c|c|c|c|c|c|c|}
\hline No & Variabel & $\begin{array}{c}\text { Definisi } \\
\text { operasional dan } \\
\text { Referensi }\end{array}$ & & Indikator & $\begin{array}{l}\text { Pernyataan dari } \\
\text { penelitian yang } \\
\text { telah dilakukan }\end{array}$ & $\begin{array}{l}\text { Pernyataan } \\
\text { yang dipakai } \\
\text { dalam } \\
\text { penelitian ini }\end{array}$ & Skala \\
\hline 1 & $\begin{array}{c}\text { CSR Dana } \\
\text { Pendidikan (X) }\end{array}$ & $\begin{array}{l}\text { Tanggung jawab } \\
\text { sosial adalah } \\
\text { tanggung jawab } \\
\text { perusahaan } \\
\text { terhadap semua } \\
\text { kegiatan yang }\end{array}$ & $\begin{array}{l}1 . \\
2 .\end{array}$ & $\begin{array}{l}\text { Konsep CSR } \\
\text { Implementasi } \\
\text { program CSR }\end{array}$ & $\begin{array}{l}\text { 1. Filosofi dan } \\
\text { tujuan } \\
\text { program CSR } \\
\text { 2. Model } \\
\text { program CSR }\end{array}$ & $\begin{array}{l}\text { 1. Proses awal } \\
\text { pelaksanaan } \\
\text { program }\end{array}$ & Ordinal \\
\hline
\end{tabular}




\begin{tabular}{|c|c|c|c|c|c|c|}
\hline No & Variabel & $\begin{array}{c}\text { Definisi } \\
\text { operasional dan } \\
\text { Referensi }\end{array}$ & Indikator & $\begin{array}{l}\text { Pernyataan dari } \\
\text { penelitian yang } \\
\text { telah dilakukan }\end{array}$ & $\begin{array}{c}\text { Pernyataan } \\
\text { yang dipakai } \\
\text { dalam } \\
\text { penelitian ini }\end{array}$ & Skala \\
\hline & & $\begin{array}{c}\text { manusia, } \\
\text { komunitas } \\
\text { mereka dan } \\
\text { lingkungan. Hal } \\
\text { tersebut akan } \\
\text { berdampak } \\
\text { kepada } \\
\text { kesejahteraan } \\
\text { masyarakat. } \\
\text { Mulyadi (2007) }\end{array}$ & $\begin{array}{l}\text { 3. Hasil dari } \\
\text { implementasi } \\
\text { program CSR } \\
\text { Suharto } \\
(2009: 115)\end{array}$ & $\begin{array}{l}\text { 3. Strategi CSR } \\
\text { 4. Pelaksanaan } \\
\text { program CSR } \\
\text { 5. Hasil yang } \\
\text { diperoleh } \\
\text { melalui } \\
\text { program CSR }\end{array}$ & $\begin{array}{l}\text { 2. Program CSR } \\
\text { apa saja yang } \\
\text { di laksanakan } \\
\text { 3. Terlibat } \\
\text { dalam semua } \\
\text { kegiatan dari } \\
\text { mulai } \\
\text { sosialisasi, } \\
\text { pelaksanaan, } \\
\text { dan evaluasi } \\
\text { program CSR } \\
\text { 4. Pelaksanaan } \\
\text { dan hasil yang } \\
\text { diterima dari } \\
\text { program CSR } \\
\\
\text { 5. Program CSR } \\
\text { meningkatkan } \\
\text { kesejahteraan } \\
\text { masyrakat }\end{array}$ & \\
\hline 2 & $\begin{array}{c}\text { Kesejahteraan } \\
\text { Masyarakat } \\
\text { (Y) }\end{array}$ & $\begin{array}{l}\text { Suatu kondisi } \\
\text { terpenuhinya } \\
\text { kebutuhan } \\
\text { material, } \\
\text { spritual, dan } \\
\text { sosial warga } \\
\text { negara agar } \\
\text { dapat hidup } \\
\text { layak dan } \\
\text { mampu } \\
\text { mengembangkan } \\
\text { diri, sehingga } \\
\text { dapat } \\
\text { melaksanakan } \\
\text { fungsi sosialnya } \\
\text { Undang-Undang } \\
\text { Republik } \\
\text { Indonesia Nomor } \\
\text { 11 Tahun 2009 }\end{array}$ & $\begin{array}{l}\text { 1. Penghasilan } \\
\text { Keluarga } \\
\begin{array}{c}\text { 2. Kebutuhan } \\
\text { hidup sehari- } \\
\text { hari }\end{array} \\
\text { 3. Biaya } \\
\text { Pendidikan } \\
\text { anak } \\
\text { 4. Lingkungan } \\
\text { yang sehat } \\
\text { 5. Tempat tinggal } \\
\text { yang layak } \\
\text { 6. Masa depan } \\
\text { yang lebih baik }\end{array}$ & 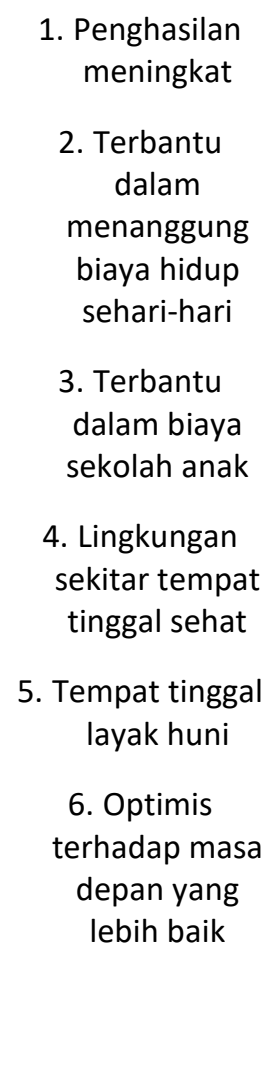 & 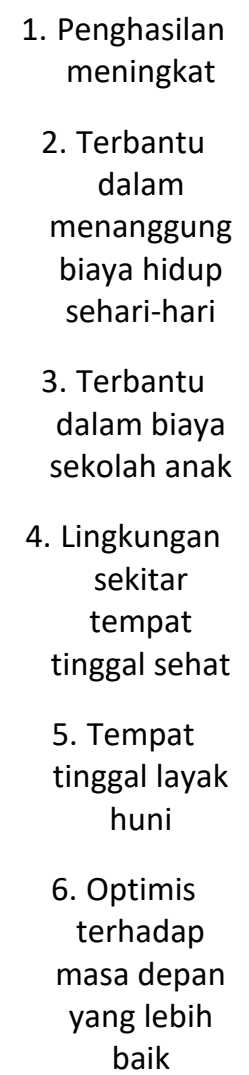 & Ordinal \\
\hline
\end{tabular}


Skala pengukuran yang digunakan oleh peneliti untuk menyatakan tanggapan dari responden terhadap setiap pertanyaan yang diberikan adalah dengan menggunakan Skala Likert dengan 5 skala. Menurut Sugiyono (2013) Skala Likert digunakan untuk mengukur sikap, pendapat, dan persepsi seseorang atau sekelompok orang tentang fenomenasosial.

Teknik sampling atau penarikan sampel yang digunakan adalah non probability sampling yang merupakan teknik pengambilan sampel yang tidak memberikan peluang sama untuk dipilih menjadi sampel, untuk itu pengambilan sampel ini penulis menggunakan metode sampling jenuh. Pengertian sampling jenuh menurut Sugiyono (2013:78) adalah sebagai berikut:

"Sampling Jenuh adalah teknik penentuan sample bila semua anggota populasi digunakan sebagai sampel."

Berdasarkan teknik pengambilan sampel di atas dengan menggunakan teknik sampling Jenuh untuk masing-masing program CSR sebanyak 50 orang untuk penerima bantuan program CSR Pendidikan di Distrik Ulilin Kabupaten Merauke, maka yang diambil sebagai sampel adalah sebanyak 50 orang.

\section{HASIL DAN PEMBAHASAN}

\section{Uji Validitas}

Uji validitas ini dimaksudkan untuk menguji valid atau tidaknya suatu pertanyaan dalam kuesioner. Suatu pertanyaan dikatakan sahih atau valid apabila pertanyaan pada kuesioner mampu mengungkapkan sesuatu yang hendak diukur oleh kuesioner tersebut dan memiliki koefisien validitas yang lebih besar dari nilai kritis yang direkomendasikan, yaitu sebesar 0,273. Rekapitulasi hasil pengujian validitas disajikan pada tabel berikut :

Tabel 2. Hasil Uji Validitas

\begin{tabular}{ccccc}
\hline Variabel & $\begin{array}{c}\text { No. } \\
\text { Item }\end{array}$ & $\begin{array}{c}r \\
\text { hitung }\end{array}$ & $\begin{array}{c}r \\
\text { tabel }\end{array}$ & Keterangan \\
\hline & 1 & 0,809 & 0,273 & Valid \\
CSR & 2 & 0,691 & 0,273 & Valid \\
Pendidikan (X) & 3 & 0,800 & 0,273 & Valid \\
& 4 & 0,793 & 0,273 & Valid \\
& 5 & 0,453 & 0,273 & Valid \\
& 6 & 0,792 & 0,273 & Valid \\
& 1 & 0,743 & 0,273 & Valid \\
& 2 & 0,819 & 0,273 & Valid \\
\hline
\end{tabular}

\begin{tabular}{ccccc}
\hline Variabel & $\begin{array}{c}\text { No. } \\
\text { Item }\end{array}$ & $\begin{array}{c}r \\
\text { hitung }\end{array}$ & $\begin{array}{c}r \\
\text { tabel }\end{array}$ & Keterangan \\
\hline Kesejahteraan & 3 & 0,728 & 0,273 & Valid \\
Masyarakat & 4 & 0,632 & 0,273 & Valid \\
(Y) & 5 & 0,684 & 0,273 & Valid \\
& 6 & 0,796 & 0,273 & Valid \\
\hline
\end{tabular}

Sumber : Hasil Olah Data SPSS Versi 23.0, 2019

Pada Tabel 2, dapat dilihat bahwa seluruh pertanyaan yang digunakan untuk mengukur variabel CSR Pendidikan (X) terhadap Kesejahteraan masyarakat $(Y)$ memiliki nilai $r$ hitung yang lebih besar dari 0,273 (nilai $r$ tabel), sehingga seluruh pertanyaan pada variabel tersebut dinyatakan valid.

\section{Uji Reliabilitas}

Dalam penelitian ini, untuk menguji konsistensi alat ukur penelitian, peneliti menggunakan metode Cronbach's Alpha. Suatu konstruk atau variabel dapat diterima apabila memiliki koefisien reliabilitas yang lebih besar dari 0,60. Rekapitulasi hasil pengujian reliabilitas dapat dilihat pada tabel berikut :

Tabel 3. Hasil Uji Reliabilitas

\begin{tabular}{cccc} 
Variabel & $\begin{array}{c}\text { Koefisien } \\
\text { Reliabilitas }\end{array}$ & $\begin{array}{c}\text { Titik } \\
\text { Kritis }\end{array}$ & Keterangan \\
\hline $\begin{array}{c}\text { CSR Pendidikan }(\mathrm{X}) \\
\text { Kesejahteraan } \\
\text { Masyarakat (Y) }\end{array}$ & 0,823 & 0,600 & Reliabel \\
\hline
\end{tabular}

Sumber : Hasil Olah Data SPSS Versi 23.0, 2019

Pada Tabel 3, dapat dilihat bahwa tidak terdapat variabel yang memiliki nilai Cronbach's Alpha lebih kecil dari 0,60 sehingga seluruh pertanyaan pada ketiga variabel dinyatakan reliabel.

\section{Uji Normalitas}

Hasil uji normalitas dengan menggunakan SPSS versi 23.0 untuk variabel penelitian ditunjukkan dengan tabel 4 dibawah ini:

Tabel 4. Hasil Uji Normalitas One-Sample Kolmogorov-Smirnov Test

$\begin{array}{cc}\text { Kolmogorov-Smirnov Z } & 0.052 \\ \text { Asymp. Sig. (2-tailed) } & 0.200\end{array}$

Sumber : Hasil Olah Data SPSS Versi 23.0, 2019

Berdasarkan tabel diatas, dapat disimpulkan bahwa data terdistribusi normal terlihat dari hasil pengujian menggunakan uji statistik Kolmogorov-Smirnov (K-S), dimana hasil 
Kolmogrov-Smirnov menunjukkan angka 0.052 dengan tingkat signifikansi yang berarti berada diatas 0.05 dengan demikian dapat disimpulkan bahwa variabel terdistribusi secara normal.

\section{Uji Heterokedastisitas}

Pada tabel 5 berikut dapat dilihat nilai signifikansi koefisien korelasi variabel:

Tabel 5. Hasil Uji Heterokedastisitas

\begin{tabular}{ccc}
\hline Model & & Sig. \\
\hline \multirow{2}{*}{1} & (Constant) & 0.015 \\
& CSR Dana Pendidikan & 0.884
\end{tabular}

Sumber : Hasil Olah Data SPSS Versi 23.0, 2019

Berdasarkan koefisien korelasi yang diperoleh seperti disajikan pada tabel 5 diatas memberikan suatu indikasi bahwa residual (error) yang muncul dari persamaan regresi mempunyai varians yang sama (tidak terjadi heteroskedastisitas). Hal ini terlihat dari nilai signifikansi masing-masing korelasi variabel CSR Pendidikan $(X)$ dengan residual (yaitu 0.884) masih lebih besar dari 0,05.

\section{Analisis Korelasi}

Tabel 6. Hasil Uji Korelasi Pearson

\begin{tabular}{cccr}
\multicolumn{4}{c}{ Correlations } \\
\hline & $\begin{array}{c}\text { CSR } \\
\text { Pendidikan }\end{array}$ & $\begin{array}{c}\text { Kesejahteraan } \\
\text { Masyarakat }\end{array}$ \\
\hline $\begin{array}{c}\text { CSR } \\
\text { Pendidikan }\end{array}$ & $\begin{array}{c}\text { Pearson } \\
\text { Correlation } \\
\text { Sig. (2-tailed) }\end{array}$ & 1 &, $712^{* *}$ \\
& $\mathrm{~N}$ & 50 & .000 \\
$\begin{array}{c}\text { Kesejahtera } \\
\text { an }\end{array}$ & $\begin{array}{c}\text { Pearson } \\
\text { Correlation } \\
\text { Masyarakat }\end{array}$ &, $712^{* *}$ & 50 \\
& Sig. (2-tailed) & & 1 \\
& & .000 &
\end{tabular}

$$
\text { N }{ }^{* *} \text {. Correlation is significant at the } 0.01 \text { level (2-tailed). }
$$

Sumber : Hasil Olah Data SPSS Versi 23.0, 2019

Berdasarkan Tabel 6 terlihat bahwa nilai koefisein korelasi yang diperoleh CSR pendidikan $(\mathrm{X})$ dengan kesejahteraan masyarakat $(\mathrm{Y})$ sebesar 0,712 . Nilai korelasi bertanda positif yang menunjukkan bahwa hubungan yang terjadi antara variabel bebas dengan variabel terikat adalah searah, dimana semakin baik program CSR pendidikan yang dijalankan maka akan diikuti semakin meningkatnya kesejahteraan masyarakat. Berdasarkan kriteria interpretasi koefisien korelasi, nilai korelasi sebesar 0,712 termasuk dalam kategori hubungan yang kuat, berada pada interval 0,70-0,90.

\begin{tabular}{|c|c|c|c|c|}
\hline \multicolumn{5}{|c|}{ Model Summary } \\
\hline Model & $\mathrm{R}$ & R Square & $\begin{array}{l}\text { Adjusted } \\
\text { R Square }\end{array}$ & $\begin{array}{l}\text { Std. } \\
\text { Error of } \\
\text { the } \\
\text { Estimate }\end{array}$ \\
\hline 1 &, $712^{a}$ & .507 & .497 & 2.60059 \\
\hline
\end{tabular}

Koefisien Determinasi

Tabel 7. Koefisien Determinasi CSR Pendidikan

Sumber : Hasil Olah Data SPSS Versi 23.0, 2019

Berasarkan tabel 7, nilai koefisien determinasi sebesar $50.7 \%$ menunjukkan bahwa CSR Pendidikan (X) memberikan pengaruh secara simultan sebesar $50.7 \%$ terhadap kesejahteraan masyarakat (Y). Sedangkan sisanya sebesar 49.3\% merupakan kontribusi faktor lain selain CSR pendidikan yang tidak diamati di dalam penelitian ini.

\section{Analisis Regresi}

Berdasarkan hasil perhitungan, maka persamaan regresi linier sederhana seperti dalam

\begin{tabular}{|c|c|c|c|c|c|c|}
\hline \multicolumn{7}{|c|}{ Coefficients $^{\mathrm{a}}$} \\
\hline \multirow{5}{*}{1} & \multirow[b]{2}{*}{ Model } & \multicolumn{2}{|c|}{$\begin{array}{r}\text { Unstandardize } \\
\text { d Coefficients } \\
\text { Std. }\end{array}$} & $\begin{array}{c}\text { Standardize } \\
\mathrm{d} \\
\text { Coefficients }\end{array}$ & \multirow[b]{2}{*}{$\mathrm{T}$} & \multirow[b]{2}{*}{ Sig. } \\
\hline & & $\mathrm{B}$ & Error & Beta & & \\
\hline & (Constant) & 1.413 & 1.445 & & .978 & .333 \\
\hline & $\begin{array}{c}\text { CSR } \\
\text { Pendidika } \\
n\end{array}$ & .708 & .101 & .712 & $\begin{array}{r}7.03 \\
3\end{array}$ & .000 \\
\hline & a. Depe & dent Var & ble: Kes & jahteraan Mas & akat & \\
\hline
\end{tabular}
tabel 8:

Tabel 8. Regresi Linier CSR Pendidikan

Sumber : Hasil Olah Data SPSS Versi 23.0, 2019

Hasil tabel 8 di atas, akan masukkan kedalam persamaan regresi, sebagai berikut:

\section{$\mathbf{Y}=\mathbf{a}+\mathbf{b X}$}

Dimana:

Y: Variabel tidak bebas (Kesejahteraan Masyarakat)
a: Bilangan berkonstanta
$\beta$ : Koefisien Regresi
$\mathrm{X}$ : CSR Pendidikan

Setelah dilakukan pengolahan data maka diperoleh persamaan regresi linier sederhana yang penulis sajikan di halaman selanjutnya, sebagai berikut.

$Y=1.413+0.708 X$ 
$\mathrm{a}=\mathbf{1 . 4 1 3}$ memiliki arti bahwa, apabila setiap variabel CSR Pendidikan sama dengan nol atau konstan maka kesejahteraan masyarakat memiliki nilai sebesar 1.413 satuan.

$\mathbf{b}=\mathbf{0 . 7 0 8}$ artinya adalah apabila variabel CSR Pendidikan mengalami peningkatan sebesar satu satuan maka nilai variabel kesejahteraan masyarakat akan diprediksikan akan mengalami peningkatan sebesar 0.708 satuan.

\section{Uji Hipotesis}

Hipotesis parsial dijelaskan kedalam bentuk statistik seperti yang tertera dibawah:

- Ho: $\beta=$ 0: Tidak terdapat pengaruh CSR Pendidikan terhadap kesejahteraan masyarakat

- $\mathrm{H}_{1}: \beta \neq 0$ : Terdapat pengaruh CSR Pendidikan terhadap kesejahteraan masyarakat

Setelah pengujian dilakukan, maka hasil perhitungan untuk masing-masing hipotesis $t_{\text {hitung, dibandingkan dengan } t_{\text {tabel }} \text { dengan taraf }}$ kesalahan 5\% uji one tailed (Sugiyono, 2015:194) dan ketentuannya, sebagai berikut:

$\mathrm{H}_{\mathrm{O}}$ ditolak, $\mathrm{H}_{\mathrm{a}}$ diterima, jika $\mathrm{T}_{\text {hitung }}>\mathrm{T}_{\text {tabel }}$ artinya terdapat pengaruh.

$\mathrm{H}_{\mathrm{O}}$ diterima, $\mathrm{H}_{\mathrm{a}}$ ditolak, jika $\mathrm{T}_{\text {hitung }}<\mathrm{T}_{\text {tabel }}$ artinya tidak ada pengaruhnya.

Tabel 9. Hasil Uji Hipotesis CSR Pendidikan

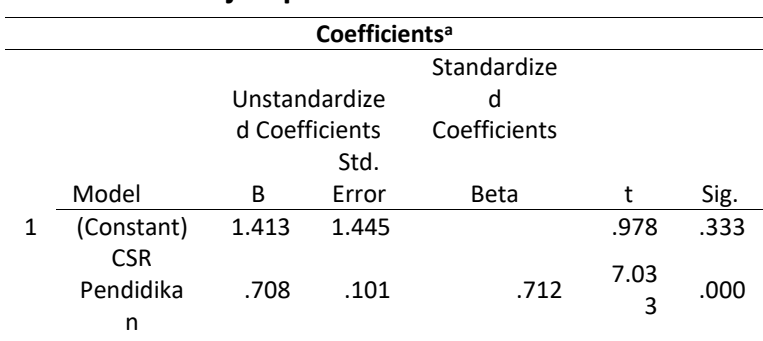

a. Dependent Variable: Kesejahteraan Masyarakat

Sumber : Hasil Olah Data SPSS Versi 23.0, 2019

Berdasarkan pada tabel 4.8 , hasil pada tabel coefficients maka dapat dijelaskan sebagai berikut: Untuk pengaruh CSR Pendidikan terhadap kesejahteraan masyarakat, diperoleh nilai thitung sebesar 7.033 dengan mengambil taraf signifikansi $\alpha$ sebesar $5 \%$, maka nilai $t_{\text {tabel }}$ atau $\mathrm{t}_{0,05.48}=2.01$, atau dengan melihat tingkat signifikan 0.000 yaitu lebih kecil dari 0.05 maka Ho ditolak atau dengan kata lain CSR Pendidikan berpengaruh positif terhadap kesejahteraan masyarakat.

\section{KESIMPULAN}

Dari hasil pengujian dengan jumlah responden penerima CSR Pendidikan sebanyak 50 orang maka hasil menunjukan bahwa variabel CSR Pendidikan berpengaruh secara positif dan signifikan terhadap kesejahteraan masyarakat. Pengaruh dari program CSR pendidikan inipun memiliki pengaruh yang cukup besar yakni $50.7 \%$ yang artinya lebih dari setengah kesejahteraan masyarakat dipengaruhi CSR pendidikan, ini artinya bahwa dengan semakin tingginya tingkat bantuan CSR pendidikan dapat meningkatkan kesejahteraan masyarakat.

\section{REKOMENDASI}

\section{Aspek Praktis}

Sebagai hasil dari penelitian dan analisis pada bab-bab sebelumnya dapat disimpulkan saransaran sebagai berikut:

a. Bagi Perusahaan

Dari hasil uji yang dipaparkan pada bagian pembahasan maka perusahaan harus lebih aktif dalam mensosialisasikan programprogram CSR Pendidikan karena memiliki pengaruh yang cukup besar dalam kontribusi tingkat kesejahteraan, juga berkaitan dengan masa depan anak-anak di Distrik Ulilin Kabupaten Merauke dan akan jauh lebih bermanfaat bagi kesejahteraan masyarakat di masa yang akan datang.

b. Bagi Pemerintah Daerah

Hasil penelitian ini dapat menjadi tolak ukur dalam meningkatkan kesejahteraan masyarakat terutama yang berada di Distrik Ulilin Kabupaten Merauke, dimana kesejahteraan masyarakat sangat dipengaruhi oleh pendidikan. Diharapkan pemerintah dapat lebih memfokuskan dan membantu dalam meningkatkan fasilitas pendidikan.

\section{Aspek Teoritis}

Berdasarkan hasil penelitian ini, penulis mencoba memberikan saran bagi penelitian selanjutnya, yaitu

a. Penelitian selanjutnya, sebaiknya melakukan penyebaran dan pengumpulan kuesioner dengan mempertimbangkan masyarakat penerima bantuan program CSR selain Pendidikan sehingga dapat diperoleh dampak pemberian CSR yang lebih 
menyeluruh bagi masyarakat dan perusahaan.

b. Diharapkan peneliti selanjutnya dapat memperluas wilayah penelitian dengan mengambil sampel tidak hanya masyarakat di satu Distrik penerima bantuan saja sehingga diperoleh hasil penelitian yang tingkat generalisasinya lebih tinggi.

\section{DAFTAR PUSTAKA}

Astiti, N. P. Y., dan Saitri, P. W. (2016). Pengaruh Corporate Social Responsibility Terhadap Kesejahteraan Masyarakat Dan Citra Perusahaan. Jurnal Bisnis dan Kewirausahaan, 12(2), 94-104.

Fitri, A. M. (2015). Pengaruh Corporate Social Responsibility, Leverage, Likuiditas dan Ukuran Perusahaan Terhadap Agresivitas Pajak. Jurnal Online Mahasiswa, 2(2), 1-15.

Mapasingka, A. (2009). Implementasi CSR terhadap Kesejahteraan Hidup Masyarakat. Jurnal Ekonomi dan Studi Pembangunan, 1(1), 39-47.

Mardikanto, T. (2014). CSR (Corporate Social Responsibility). Bandung: Alfabeta.

Morissan. (2012). Metode Penelitian Survey. Jakarta: Kencana Prenada Media Group

Mulyadi. (2007). Sistem Perencanaan dan Pengendalian Manajemen, Edisi ke-3, Jakarta: Salemba Empat.

Nurbaety, A., Ratnasih, R., dan Ramdan, H. (2015). Analisis Implementasi Corporate Social Responsibility PT Bio Farma di Desa Sukamulya Kabupaten Sukabumi. Jurnal Sosioteknologi, 14(2), 141-153.

Pemerintah Indonesia. (2007). Undang-Undang Republik Indonesia Nomor 40 Tahun 2007 tentang Perseroan Terbatas.
Lembaran RI Tahun 2007 No. 4756. Jakarta : Sekretariat Negara.

Pemerintah Indonesia. (2009). Undang-Undang Republik Indonesia Nomor 11 Tahun 2009 tentang Kesejahteraan Sosial. Lembaran RI Tahun 2007 No. 4967. Jakarta : Sekretariat Negara.

Pradipta \& Supriyadi. (2015). Pengaruh Corporate Social Responsibility (CSR), Profitabilitas, Leverage, dan Komisaris Independen Terhadap Praktik Penghindaran Pajak. Jurnal Universitas Gadjah Mada.

Sanusi, A. (2013). Metodologi Penelitian Bisnis. Cetakan Ketiga. Jakarta: Salemba Empat.

Suharto, E., 2009. Pekerjaan Sosial di Dunia Industri CSR. Bandung: Alfabeta Bandung.

Sugiyono. 2013. Memahami Penelitian Kualitatif. Bandung: ALFABETA.

Susenas Badan Pusat Statistik. (2015). Statistik Pendidikan dan Kesejahteraan Sosial Badan Pusat Statistik. Dalam diakses https://mikrodata.bps.go.id, diakses pada tanggal 12 Januari 2019 pada jam 15.33 WIB 